\section{'Sunsplash' Nectarine}

\section{Gerard Krewer ${ }^{1}$}

Horticulture Department, University of Georgia, P.O. Box 1209, Tifton, GA 31793

\section{Thomas Beckman ${ }^{2}$}

U.S. Department of Agriculture, Agricultural Research Service, Southeastern Fruit and Tree Nut Laboratory, 111 Dunbar Road, Byron, GA 31008

Wayne Sherman ${ }^{3}$

Department of Horticultural Sciences, University of Florida, 1137 Fifield Hall, Gainesville, FL 32611

\section{Additional index words. Prunus persica, peach, low chilling, fruit breeding}

'Sunsplash' nectarine [Prunus persica (L.) Batsch] was jointly released by the Univ. of Georgia, Univ. of Florida, and U.S. Dept. of Agriculture to provide an early ripening nectarine for commercial markets. Names of nectarines released or jointly released by the Univ. of Florida begin with the prefix "Sun." 'Sunsplash' is expected to be successful for homegardeners, u-pick, local markets, and commercial shippers in areas where 'Flordaking' is well adapted. This area is a belt running from southeastern South Carolina through southern Georgia and northern Florida to south-central Texas.

\section{Origin}

'Sunsplash' originated in Gainesville, Fla., from a 1977 cross of 'Sunlite' X 'Armking'; it was selected and propagated in 1978 and tested as Florida $8-2 \mathrm{~N}$. Budded or own-rooted trees have been tested in Georgia at the Univ. of Georgia research farm near Morven, at the U.S. Dept. of Agriculture station in Byron, and at commercial farms near Blackshear, Ocilla, Tifton, and Quitman.

Budded trees have been tested in Florida at the Fruit Crops Dept. in Gainesville, and in Australia (Firth et al., 1991).

\section{Description}

'Sunsplash' fruit have been observed on budded trees since 1979. Trees are vigorous and semi-spreading and set a moderately high number of flower buds, slightly higher than 'Flordaking'. They require a moderate amount of fruit thinning in the absence of thinning by spring freezes. Fruit are medium size for early season fruit, averaging $\approx 55 \mathrm{~mm}$ in diameter when thinned to 15 to $20 \mathrm{~cm}$ apart (Table 1). Fruit ripen 68 to 80 days from full bloom

Received for publication 17 May 1993. Accepted for publication 7 Oct. 1993. The cost of publishing this paper was defrayed in part by the payment of page charges. Under postal regulations, this paper therefore must be hereby marked advertisement solely to indicate this fact.

${ }^{1}$ Associate Professor.

2Research Horticulturist.

${ }^{3}$ Professor.

HORTSCIENCE, VOL. 29(4), APRIL 1994

freestone when soft ripe. Flesh is melting, yellow with streaks of red, firm, and, in our opinion, with good to excellent quality. Flesh browning does not occur readily on cut surfaces. External fruit appearance is attractive, with $40 \%$ to $90 \%$ red blush over a bright yellow ground color. 'Sunsplash' exhibits some russetting and ridges on the fruit surface in some years. Pits have little tendency to split, but fruit skin cracking has been a problem on some sandy sites in a few years. At a test location in Australia, there has been a tendency for 'Sunsplash' to be soft on the suture (Firth et al., 1991). In Georgia, 'Sunsplash' has been superior to 'Sungem' (Table 2). 'Sunsplash' has fewer split pits and more exposed ground color, allowing maturity to be easily determined for individual fruit.

Harvest period, which lasts $\approx 7$ days, begins in southern Georgia in early to mid-May of most years and usually follows 'Flordaking' peach.

Leaves are moderately large with globose petiolar glands. Bacterial spot [Xanthomonas slight tip in some years (Fig. 1). Fruit are semiing 'Sunsplash' one of the first nectarines to ripen in southern Georgia. Fruit are somewhat

Table 1. Fruit characteristics of 'Sunsplash' nectarine at Tifton, Ga. (1985-91).

\begin{tabular}{|c|c|c|c|c|c|c|c|c|c|}
\hline Year & $\begin{array}{l}\text { Tree } \\
\text { age } \\
\text { (years) }\end{array}$ & $\begin{array}{c}\text { Full } \\
\text { bloom } \\
\text { date }\end{array}$ & $\begin{array}{c}\text { Fruit } \\
\text { harvest } \\
\text { date }\end{array}$ & $\begin{array}{l}\text { Crop } \\
\text { load }\end{array}$ & $\begin{array}{c}\text { Fruit } \\
\text { ring } \\
\text { size }(\mathrm{mm})\end{array}$ & $\begin{array}{l}\text { Fruit } \\
\text { shape }\end{array}$ & $\begin{array}{l}\text { Red } \\
\text { over } \\
\text { color } \\
(\%)\end{array}$ & $\begin{array}{c}\text { Attractive- } \\
\text { ness }^{y}\end{array}$ & Flavor $^{y}$ \\
\hline 1985 & 2 & 5 Mar. & 12 May & 10 & $51-54$ & 7 & 40 & 7 & 6 \\
\hline 1986 & 3 & $24 \mathrm{Feb}$. & 12 May & 10 & $51-63$ & 7 & 90 & 8 & 7 \\
\hline $1987^{x}$ & 4 & 9 Mar. & 19 May & 10 & $51-57$ & 7 & 55 & 7 & 7 \\
\hline 1988 & 5 & 2 Mar. & 19 May & 10 & $51-63$ & 7 & 70 & 7 & 8 \\
\hline 1989 & 6 & $6 \mathrm{Feb}$ & $\mathrm{NA}^{\mathrm{w}}$ & $\mathrm{NA}^{\mathrm{r}}$ & NA & NA & NA & NA & NA \\
\hline 1990 & 7 & 7 Feb. & $25 \mathrm{Apr}$. & 10 & NA & 7 & NA & 6 & 8 \\
\hline 1991 & 8 & $20 \mathrm{Feb}$. & 11 May & 10 & $51-58$ & 6 & 90 & 7 & 7 \\
\hline
\end{tabular}

${ }^{2}$ Crop load rating: $0=$ no crop; $10=$ full crop.

'Shape, flavor, attractiveness ratings: $1=$ least desirable; $10=$ most desirable.

Data from Univ. of Georgia research farm near Morven.

"Information is not available.

${ }^{v}$ Crop destroyed by spring freeze.

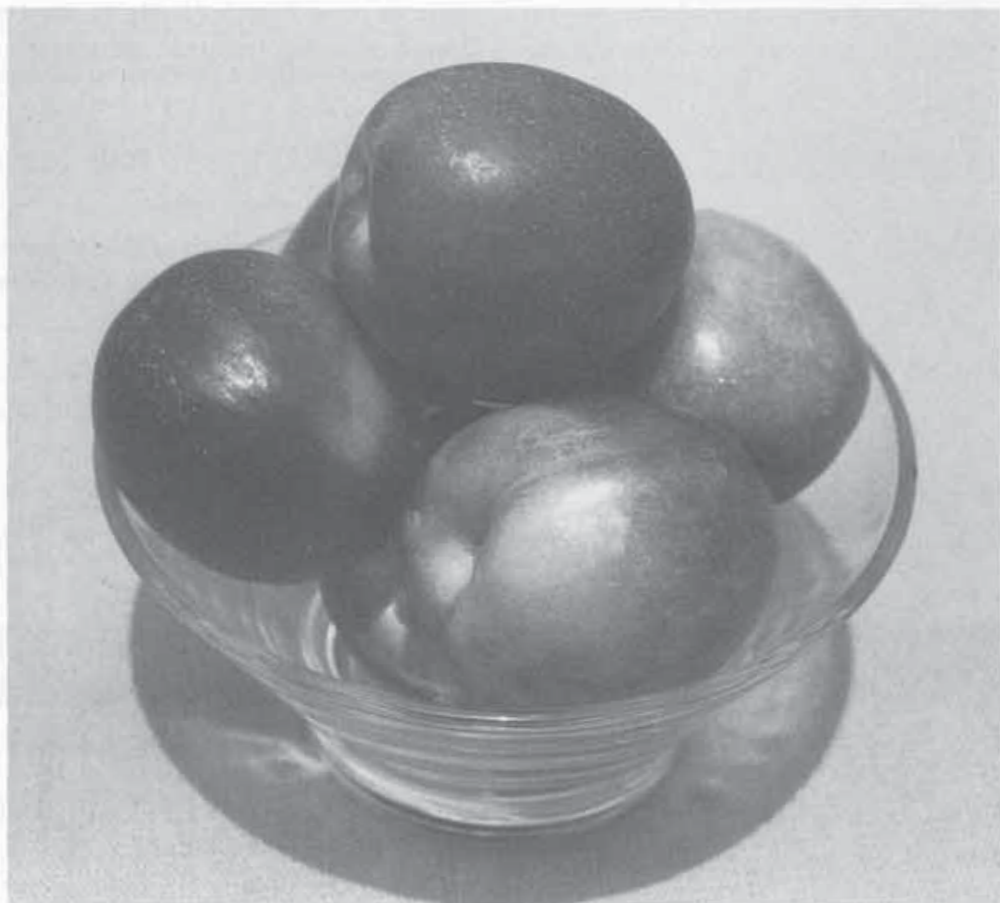

Fig. 1. Typical fruit of 'Sunsplash' nectarine. 
Table 2. Performance of six nectarine cultivars at Tifton, Ga. (1986-91).

\begin{tabular}{|c|c|c|c|c|c|c|c|c|c|c|}
\hline Cultivar & $\begin{array}{l}\text { Chilling } \\
\text { hours }^{2}\end{array}$ & $\begin{array}{c}\text { Fruit } \\
\text { harvest } \\
\text { date }\end{array}$ & $\begin{array}{l}\text { Crop } \\
\text { load }\end{array}$ & $\begin{array}{c}\begin{array}{c}\text { Fruit } \\
\text { ring } \\
\text { size }(\mathrm{mm})\end{array}\end{array}$ & $\begin{array}{l}\text { Fruit } \\
\text { shape }^{x}\end{array}$ & $\begin{array}{c}\text { Red } \\
\text { over } \\
\text { color }(\%)\end{array}$ & $\begin{array}{l}\text { Attractive- } \\
\text { ness }\end{array}$ & $\begin{array}{l}\text { Firm- } \\
\text { ness }^{x}\end{array}$ & Flavor ${ }^{2}$ & Comments \\
\hline Mayfire & 650 & 128 & 8.3 & 4.9 & 7 & 86 & 8 & 6.6 & 7.4 & $\begin{array}{l}\text { Too small for shipping; } \\
\text { soft on tip }\end{array}$ \\
\hline Sundollar ${ }^{\mathrm{w}, \mathrm{v}, \mathrm{u}}$ & 350 & 130 & 6.3 & 5.4 & 7 & 80 & 6.5 & 6 & 6 & $\begin{array}{l}\text { Reliable cropping a } \\
\text { problem in southern } \\
\text { Georgia? }\end{array}$ \\
\hline Sunsplash & 400 & 131 & 8.6 & 5.5 & 6.8 & 69 & 7 & 7 & 7.2 & $\begin{array}{l}\text { Fruit cracking an } \\
\text { occasional problem }\end{array}$ \\
\hline Sungem ${ }^{v, r}$ & 450 & 131 & 7.3 & 5.4 & 6.8 & 79 & 6.8 & 7 & 6.8 & $\begin{array}{l}\text { Split pits a problem; } \\
\text { dark color }\end{array}$ \\
\hline Armking & 550 & 136 & 9.2 & 5.4 & 6.0 & 85 & 6 & 6 & 6.2 & $\begin{array}{l}\text { Soft on tip; } \\
\text { unattractive }\end{array}$ \\
\hline Sunfre $e^{u, t}$ & 525 & 144 & 7.0 & 6.1 & 7.5 & 76 & 6.8 & 7 & 7 & $\begin{array}{l}\text { Color somewhat dark; } \\
\text { green ground color } \\
\text { until nearly fully ripe }\end{array}$ \\
\hline
\end{tabular}

${ }^{x}$ Hours at or below $7.2 \mathrm{C}$.

yulian date.

*Rated on a scale of 1 to 10 , where 10 is most desirable.

"Limited data collected in 1990.

"Spring freeze destroyed crop in 1989.

"Data from 1988 to 1991.

'1990 data from U.S. Dept. of Agriculture farm near Morven, Ga.

campestris pv.pruni $(\mathrm{Sm}$.) Dye] resistance is moderately high, equivalent to 'Sunlite'. The fruit is moderately susceptible to brown rot [Monilinia fructicola (Wint.) Honey] and requires a good disease control program, as do all nectarines in the southeastern United States. Flowers are large, showy, and medium pink. Pollen is bright yellow and abundant. Trees are self-fruitful. Major advantages of 'Sunsplash' nectarine are its attractive fruit, high and regular fruitfulness, and early ripening.

Several other nectarine cultivars adapted to this region ripen about the same time as 'Sunsplash', e.g., 'Mayfire', 'Sundollar', and 'Sungem' (Table 2). However, 'Sunsplash' offers advantages over each of these cultivars. Compared to 'Mayfire', 'Sunsplash' is larger and firmer. 'Sunsplash's chief advantage over 'Sundollar' is its more reliable cropping his- tory as one moves north in the Coastal Plain. However, in northern Florida growing areas, 'Sundollar' is slightly superior to 'Sunsplash' (P.C. Andersen, personal communication). Compared to 'Sungem', 'Sunsplash' offers fewer split pits and a more attractive appearance (Table 2).

\section{Culture}

'Sunsplash' trees have an estimated winter-chilling requirement of 400 chill hours (hours at or below 7.2C to break dormancy) based on relative bloom time with other cultivars. Full bloom at Tifton is about the same as 'Flordaking' peach. It has fruited well where the coldest month (January) averages 11 to 14C. Fuil bloom occurs most seasons in February or early March (Table 1). Best adaptation would be in areas and sites where
'Flordaking' peach has proven reliable in production.

\section{Availability}

Inquiries regarding availability of 'Sunsplash' trees may be directed to commercial peach and nectarine nurseries. Limited quantities of budwood indexed free of prunus necrotic ringspot and prune dwarf viruses may be obtained from G.K., Horticulture Dept., Univ. of Georgia, P.O. Box 1209, Tifton, GA 31793.

\section{Literature Cited}

Firth, D.J., M.R. Loebel, and R. Sweedman. 1991. The successful introduction and assessment of low-chill stonefruit in Australia. Fruit Var. J. 45(3):135-142. 